\title{
ЯЗЫКОЗНАНИЕ
}

UDC 811.113.4

Elena Gurova

St. Petersburg State University

\section{INTERROGATIVES AS A MEANS TO EXPRESS POLITENESS IN THE DANISH LANGUAGE*}

For citation: Gurova E. Interrogatives as a means to express politeness in the danish language. Scandinavian Philology, 2020, vol. 18, issue 2, pp. 225-245. https://doi.org/10.21638/11701/spbu21.2020.201

Despite the change in the Danish communication style caused by the transformation of the social-political and cultural life of the Danish in the late 1960s, which made a number of polite forms obsolete, the Danish language has various ways to express polite requests. One of the most common strategies congruent with the principle of politeness and efficiency is the use of conventional interrogative sentences with the verbs gide, ville, kunne, verbs in the present tense and a construction er $d u$ sød at. The article examines these interrogative sentences gleaned from dialogues in contemporary Danish television series. The most polite of all the conventional requests are questions with vil/ville, which can be used in a formal setting or in correspondence. They appeal to the addressee's willingness to perform an action, to a greater extent than questions with kun/kunne, and they are meant to avoid encroaching upon the interlocutor's freedom. The construction er $d u$ sød at is classed among the formulas of a high degree of politeness and often presupposes a significant status distance between the interlocutors. Questions with gide are used when social and status distance between the interlocutors is insignificant. Combinations of gide and vil with phasal verbs denoting the ending of an action indicate that these constructions perform a prohibitive function. In the case of questions in the present tense, the interlocutors, as a rule, are engaged in a common activity and the effect of the proposed action is in the interest of both parties. A chara-

* With the support from the Russian Foundation for Fundamental Research (RFFR), grant No. 19-012-00146. 
cteristic feature of the speech act of requests is the use of modal particles, first and foremost, ikke and lige. The particle lige is a culture-specific lexical item which indicates that the favour done by the listener is insignificant, but in spite of a lesser threat posed by the speaker, his expressed will is imposed since it is the speaker who decides for the listener how insignificant his request is. The particles godt and nok are used in insistent requests, while combinations with bare imply a mutually satisfying way to solve the problem at hand.

Keywords: the Danish language, politeness, interrogative questions, indirect requests, communication style.

Numerous contemporary studies conducted in various dimensions are devoted to the study of politeness. Works by Penelope Brown and Stephen Levinson, Paul Grice, Robin Lakoff, and Geoffrey Leech describing the politeness phenomenon have become classical and laid the foundations for further research into the matter as reflected in different languages [Brown, Levinson, 1987; Lakoff, 1973; Grice, 1975; Leech 1983]. Many Danish scholars examine politeness in socio-cultural terms and in the framework of etiquette proper [Andersen, 2014; Olesen, 2009; Steno, 2011; AP, 2010; Christensen, 1999]. Linguistic studies touching upon the category of politeness, as a rule, are devoted to separate aspects - the etiquette formulas of greetings [Hørning, 2015; Lund, 2008, 2011, 2014, 2015; Ronnøe, 2015; Gurova, 2017], the Thou-You forms of communication [Bjerrum, 1995; Hagemann, 1988; Hansen, 1998; Gurova, 2016]. The class of imperative speech acts also ranks high in the works by Danish researchers [Hansen, 1974; Durst-Andersen, 1995; Talbro, 2000; Hansen, 2002; Christensen, 2008; Nikulicheva, 2016]; over the recent years a number of contrastive studies related to the phenomenon of politeness in different cultures and identifying culture-specific elements of Danish communication behaviour as compared with other linguocultures have been published [Mosegaard Hansen, 1998; Fredsted, 2005; Holberg, 2014; Rykov Ibsen, 2016].

While examining the issues related to the phenomenon of politeness one must consider the following aspects.

- Politeness is a nation-specific category which cannot be defined unequivocally since different peoples see it in a different way [Larina, 2009, p. 130]. This perception stems from a certain system of values acting as vital guiding principles reflected in language and discourse. Thus, Carsten Levisen and Sophia Waters claim that, contrary to the English word politeness reigning supreme in 
the Anglo English realm of meaning, the Danish words høflighed 'pleasant togetherness' and tryghed 'sense of security' are of much greater prominence in discourse. [Levisen, Waters, 2015, p. 249]. It is no wonder that from the English standpoint the Danish look rude and impolite [Booth, 2017, p. 53] because the Danish language lacks the familiar formulas of etiquette the English hold dear: there is no equivalent of the English please, and, according to Richard Jenkins, the Danish just ask for something without further ado: "Two pastries", "A coffee, thanks", or "I'll have two of those, there", and so on. [Jenkins, 2011, p.43]. In the anthropologist Dennis Nørmark's opinion, politeness is always conditioned by the expectations of society, and in Denmark these expectations are rather subdued since everyone must be equal and nobody must stand out [Steno, 2015, s. 44]. The use of polite phrases widens the gap between communicants as the interlocutor's social role in this case becomes either more or less important, which, from the viewpoint of Danish native speakers who are used to conversing as equals, is far from desirable [Steno, 2015, s. 44].

- Both the surrounding world and language on the whole, speaking etiquette, which objectivizes the communicative category of politeness, is subject to change. Changes in socio-political and cultural life of the Danish at the end of the 1960s and the ubiquitous shift to 'thou' had an impact on the manner of behaviour and resulted in the informality that many other Europeans find too unsubtle [Palmgren, 2008, s. 10]. Many formulas of etiquette are gradually receding from active usage or start being used in the joking-ironic vein. For example, as Jenkins points out, 'vær så venlig' found in dictionaries and phrase books as an equivalent of 'please' literally means 'to be friendly' and is used rather infrequently in an ironic or sarcastic sense [Jenkins, 2011, p.42]. Another example is a question-request with the modal verb ville 'would'. Otto Jespersen in The Philosophy of Grammar published almost a hundred years ago points out the difference in the use of questions with vil and vil ikke: in Danish "Vil De række mig saltet?" is generally a command, and "Vil De ikke række mig saltet? a polite request ("Would you mind passing the salt?") [Jespersen, 1924, p. 323]. Even though in the contemporary Danish language 
both questions are taken as a polite request, the only difference is that with ikke the speaker is warier in imposing his will and seems to be foreseeing a negative response from his interlocutor. It should be noted that the speaking behaviour of contemporary people is often charged with aggressiveness. It stems from a number of adverse processes occurring in extralinguistic reality, first of all, with the acceleration of time, multi-tasking and the increase in the amount of received information. It is no wonder that a Danish company providing cellular communication services launched a campaign entitled 'Tal ordentligt' ('Speak politely') that includes making and promoting video commercials appealing to cooperative communication [Tal ordentligt].

- The degree of politeness of a certain phrase is rather conventional in principle as it can often be identified only in a context after analyzing the situation, intonation, nonverbal components, age, role and social standing of interlocutors, the nature of their relations prior to this communication, their psychological mode and physiological state. Rather indicative in this sense is an episode from the serial "Unit One" / "Mobile Unit" (Rejseholdet). An employee of Unit One, Allan Fischer, feels embarrassed seeing his colleague Gaby kiss his partner Johnny, a contract truck owner, responsible for moving the Rejseholdet mobile office between locations:

Fischer: Nårh... Kunne I ikke skride hen og gøre det et andet sted, så jeg kunne få arbejdet lidt. "Look... Can't you piss off and do that somewhere else so that I can get some work done?"

Johnny: Jo-jo. Må jeg lige spørge dig om noget? "Ok, ok. Can I just ask you something?"

Fischer: Jaja. "Of course".

Johnny: Hvorfor skal du altid snakke så grimt til mig, hvad? "Why do you always have to be so rude to me?"

Fischer: Gør jeg det? "Am I?"

Johnny: Jamen kan du ikke høre det? Hvad? Du gør da mig sgu $i$ dårligt humør, mand, hvis nu du bare sagde: "Det var hyggeligt at møde dig, Johnny, jeg har sgu noget arbejde, så er I ikke søde at smutte" - ohm - så ville jeg blive meget glad. [lille hehe-latterlyd] "Can't you hear yourself? Eh? Man, you bloody ruin my mood. If only you'd say: 'It was great to meet you, Johnny, but I've 
got some work to do so please just push off' - er - that would make me happy" [little laugh]

Fischer: Jaja, men var det ikke det, jeg gjorde? "Of course, but wasn't that what I did?"

Johnny: Toenk over det. "Think about it".

Fischer: Var det ikke det, jeg gjorde? Det var da det, det var da det jeg gjorde. "Wasn't that just what I did? That was what I did" (Rejseholdet, s. 2, afs. 7, 37:56).

Technically, a request question with the verb kunne and the negative ikke is polite. The use of the verb skride 'clear out' in the infinitive form with the adverb hen cannot be perceived as rude, contrary to the imperative Skrid 'get out!' The request is expressed without emotion, in a neutral tone, but Johnny, nonetheless, takes it as rudeness, which is clarified by a wider context. Fischer is worried about his friend and colleague, Thomas La Cour, who is suspected of murder. Moreover, his married life is in a mess, and before Johnny's appearance Gaby was asking him about his home life. Thus, the request is caused by Fischer's psychological state, and under different circumstances it may have never happened. Johnny's outburst is the outcome of the nature of relations prior to the communication situation. A little earlier, Johnny in the company of Fischer voices his opinion of La Cour's guilt, to which Fischer irritably retorts that Johnny happens to be the driver for their mobile office, and the case itself is classified. It must be Fischer's repeated demonstration of authority that provokes Johnny, who wants to be treated as an equal. That is why, the request, technically worded in accordance with the etiquette rules, is taken as impolite, even rude.

Thus, politeness is a nation-specific category that reveals itself in established etiquette formulas and conditioned by a particular communicative situation. Since it is the situation that affects the degree of politeness, the material under study is dialogues taken from a number of television series which present various situations of communication involving members of different social groups. Although they cannot be classed as spontaneous conversations since they are part of the script where all lines must sound authentic by definition, it is highly possible to make conclusions as to the frequency of real-life politeness formulas. 
Despite some polite etiquette phrases being of active use, the Danish language boasts a large number of means to express a request. According to the latest studies, the Danish style of communication is characterized by the use of direct strategies of inducement: the part of imperative utterances (in the form of bald imperatives or an imperative with modal particles) is quite prominent in informal conversation [Durst-Andersen, 1995, 2011; Holberg, 2014; Rykov Ibsen, 2016; Nikulicheva, 2016; Heinemann, Steensig, 2017; Gurova, 2020]. Another common strategy is the use of conventional indirect requests in the form of questions.

Politeness is deemed to be the main reason behind indirect requests [Searle, 1975], but, according to Eva Ogiermann, the dimensions of politeness and indirectness do not run parallel, and they are related distinctively in different cultures [Ogiermann, 2009]. As Anna Wierzbicka points out, not only do different cultures require various uses of indirect devices, but also the very notions of 'directness' and 'indirectness' fail to be universal, which makes the scholar stop differentiating between 'direct' and 'indirect' speech acts in general, at least, until a precise definition of these terms has been formulated [Wierzbicka, 2003, p. 88]. In this article, which is not a cross-cultural study, an indirect speech act is an act of communication which is complicated in comparison with the corresponding direct act by one interpretative step: it must be taken by the addressee to understand the intentional state of the speaker.

Conventional requests in the form of questions comprise questions with modal verbs kan/kunne 'can/could', vil/ville 'will/would', the verb gide 'to bother, to feel like, to take trouble to', verbs in the present tense and the construction er $d u$ sød at gøre noget 'would you be so kind / please.' All of them are subject-oriented, that is, they are meant for the listener.

Requests with the verb gide are very frequent in informal conversation. According to Maj-Britt Mosegaard Hansen, they are used when the social and status distance between interlocutors is insignificant, contrary to questions with vil(le) that presuppose a wider distance [Mosegaard Hansen, 1998, s. 26]. Requests with gide may be conditioned by the age factor. E. Hansen notes that the younger generation prefers using gider, while the elder generation vil [Mål \& Mæle, 1997, s. 4]. The same goes for the use of the infinitive with the particle at after the verb gide: Danes younger than 50 do not see a mistake in such a use [Nyt fra 
Sprognævn, 2015, s. 14-15]. The status proper of the verb gide has been ambiguous throughout the history of the Danish language. In the contemporary Danish language, gide does not belong to modal verbs and in informal conversation it occurs more often together with the particle at [Hansen, Heltoft, 2011, s. 765, s. 778]. Etymologically, the verb gide is related to the Old-Islandic geta, Gothic bigitan and derives from the root gribe 'to catch'. Initially it was used as an auxiliary verb meaning $f a$ 'to get', kunne 'could', later have lyst til 'feel like'. In the $17^{\text {th }}$ century, the verb starts combining with infinitives without the particle at, and it was not until the $20^{\text {th }}$ century that first occurrences of a full infinitive (with at) could be traced [Hansen, Heltoft, 2011, s. 1426-1427].

Among the set expressions in Den Danske Ordbog are questions Gider du ikke nok (at) / Gider du lige (at) (roughly, 'Could I (ikke nok) get you to (lige)... / Do you mind...'), which are used in informal speech to mitigate the inducement. A synonymous phrase, according to Den Danske Ordbog, is veer så venlig at '(would you) be so kind'. The sources examined for this article did not feature the combination gide $+i k k e+$ nok. Yet, combinations with imperatives are very frequent. Normally, modal particles are considered in combination with imperatives and are deemed a distinguishing feature of the Danish communication style [Durst-Andersen, 1995, 2011; Holberg, 2014; Rykov Ibsen, 2016; Krylova, 2004, 2009, 2012, 2015; Nikulicheva, 2016; Heinemann, Steensig, 2017]. The analysis of the chosen material accords with this idea shows that modal particles that are used to express various pragmatic shades of the speaker's will are characteristic of not only directives, but also of the speech act of requests in general. Historical modal particles (dialogiske partikler) are a rather recent phenomenon. This class of words was formed only in the $19^{\text {th }}$ century [Dansk Sproghistorie, Bind 3, s. 225] and it encompasses a number of lexical items shading pragmatic meanings of the utterance.

In the contemporary Danish language, gide is used largely in negative and interrogative sentences [Jensen, 1997, s. 160]. The analysis of the assembled data shows that in conventional requests gide can be used without modal particles (1), with negation ikke (2), (4), (6), and with modal particles lige (3), (4), godt (5), (6), less often with bare (7), and these requests presuppose certain physical or mental efforts made by the addressee, that is, they are requests for action, not for a thing or permission. 
(1) Old artist to her assistant: Rene, gider du lave en kop (te) til Signe? "Rene, would you mind making Signe a cuppa?" (Arvingerne, s. 1, afs. 1, 10:19)

(2) Policeman to a colleague: Gider du ikke at skrive til dem (svensk politi) igen? "Would you mind writing to them (Swedish police) again?” (B., s. 3, afs. 7, 9:30)

(3) Teenager to a girlfriend: Gider du lige toende? (et lys i en kage) "Can you just light it? (light on a cake)". (Jul., afs. 3, 10:27)

(4) Granddad to his grandson: Gider du ikke lige give mig den mappe, der ligger i den øverste skuffe derovre? "Can you just give me the file that's over there in the top drawer?" (Theo, afs. 2, 15:53)

(5) Fisher to a mentally handicapped man: Gider du godt gå derover? Gå nu derover! "Just go over there. Get over there!" (R., 3 s., 7 afs., 39:28)

(6) Woman to her husband:

- Har du ikke lyst til at tage ned og leje en film? "Wouldn't you like to go down and borrow a film?"

- Nej, lad os heller høre den smukke musik. "No, let's rather listen to the beautiful music".

- Gider du ikke godt, Mandfred? Jeg har lyst til at se en rigtig god film. "Please Manfred. I want to see a really good film". (R., s. 3, afs. 3, 41:05)

(7) Ginger to a policeman: Gider I ikke bare gå med? Han (hendes ven) har det pissedårligt. Lad mig gå! "Can't you just come? He’s (her friend) feeling really bad. Let me go!" (Nårst., s. 1, afs. 3, 42:05)

The negative $i k k \boldsymbol{e}$ is a salient feature of indirect speech in the Danish language. According to Claus Faerch and Gabriele Kasper, the Danish when speaking German use negatives in requests more often than the Germans do, since they model upon the structure of their native language [Faerch, Kasper, 1989, p. 227]. When forming a request with $i k k e$, the speaker, as it were, expects a worst response, so he mitigates the threat for the addressee. Yet, Trine Heinemann's study examining home help service data demonstrates that a negative interrogative request presupposes the speaker's entitlement to the utterance, while the proposed act is perceived by the addressee as something that must be performed as a matter of course - contrary to the question without negation, 
which does not allow for this right [Heinemann, 2006]. For example, in (2) the policeman Alf, speaking to his subordinate, asks him, in order to step up the investigation, to repeat the enquiry to the Swedish police which is a routine practice in a particular situation for the superior and the subordinate.

Though not a true marker of politeness, the particle lige is a frequent, culture-specific lexical item having no analogies in cognate Scandinavian languages. Lige is not perceived by the Danish as a magic word like the English 'please' or the Russian 'pozhalujsta', but "Danish-speaking children are socialized into lige use, and lige thinking, from an early age" [Levisen, Waters, 2015, p. 248]. Linguistic studies regard lige as a modifier of the imperative or as part of the so-called imperative construction [Nikulicheva, 2016, s. 101]. Per Durst-Andersen classes the particle lige as an expression unit that immediately evokes a description (descriptive modalizers) that further points to a modality (alethic possibility). [Durst-Andersen, 1995, p. 641]. The particle lige usually occurs in contexts when, first, the speaker does not expect from the addressee that he will object, second, when the proposed act is not supposed to be taxing for the addressee [Hansen, Heltoft, 2011, s. 1072; Levisen, Waters, 2015, p. 260; Nikulicheva, 2012], and, third, when for both the speaker and the hearer this act is part of a common project [Heinemann, Steensig, 2017, p.139; Samtalegrammatik]. Carsten Levisen and Waters point out that the condensed semantic meaning of lige immediately makes a reference to the social norm which prescribes an informal, but anonymous, style of using directives [Levisen, Waters, 2015, p. 261]. The analysis of the assembled data reveals that this assertion can be applied not only to directives, but also to conventional requests. Thus, in (3) the teenager Bob, waiting on the people at a family function, asks his friend Sus to help him light the candle on the cake. The question with gide mitigates his willed expression, providing the addressee with an illusion of a pragmatic option, but the marker lige testifies to the insignificance of favour, thereby the speaker decides for the hearer how trifling his request is. The ability of lige to couple with imperatives, modal verbs and verbs in the present tense in conventional requests (see below) demonstrates that this particle is characteristic of the speech act of requests on the whole. Since lige, along with other particles, is of great importance for successful natural communication and proves difficult for foreigners in mastering the Danish language, a pedagogical script, framed in English 
Natural Semantic Metalanguage for learners of Danish, compiled by Levisen and Waters is of particular practical value:

a. many people think like this:

b. when I want to say to someone else something like this: "I want you to do something", at many times it is good if I can say one other word at the same time

c. this word is lige

d. when people say this word, they think like this:

e. I want you to do something

f. this is not something big, you can do this in one moment

g. in can't be bad for you to do it

h. people do things like this at many times

i. it is good if people can think like this about many things

j. it is good if people can think like this at many times [Levisen, Waters 2015, p.260].

The particle godt is used with the verb gide, modal verbs ville, kunne, turde, måtte, mental verbs and verbs of feeling and perception and has an affirmative meaning contrary to the negative ikke (meaning 'negation of negation') [Jensen, 1997, s. 156; Krylova, 2016, s. 189]. Thus, in the sentence Jeg vil godt lave mad i morgen 'I will cook a meal tomorrow', the speaker voices his will to perform the opposite to the negative act, that is, he is not unwilling to cook a meal = agrees to cook it [Jensen, 1997, p. 163]. As the verb gide is associated with negative sentences, the particle godt in indirect requests enhances the positive meaning of the utterance. For example, in (5) the policeman Fischer tries to prevent a fight and urges the mentally challenged man to leave Otto alone, but then, when the latter will not listen, uses the directive form of the imperative. In (6), the wife, suspecting her husband of a crime, pleads with her husband in an attempt to make him leave home on the pretext of borrowing an interesting video. Thus, the particle godt is used with the verb gide in insistent requests, functionally resembling the particle nok.

The particle bare also occurs in the combination with gide, telling the hearer that he needs to make a minor effort caused by the verb to reach the desired effect [see on a similar meaning of bare + imperative Krylova, 2012; Heinemann, Steensig, 2017; Samtalegrammatik]. In (7), homeless Ginger tries to talk the policemen into helping her un- 
conscious friend, instead of checking the car stolen by her, that is, to perform a simple act of saving the man, rather than examining the car.

Levisen and Waters single out the gider-du-lige construction, which shows that one is disappointed with somebody else's breaking the norm; it thereby acts as a discouragement of socially improper behavior by adducing a number of examples with phasal verbs of the ending, such as lade vore med, stoppe, etc. [Levisen, Waters, 2015, p. 256]. Moreover, the particle lige is part of the set expression Gider du lige? with prohibitive connotation conveying a meaning of tiredness or displeasure caused by the words or actions of the partner.

(8) Mother: Vi mødtes d.1.december. Kan du huske det, John? "We met on the first of December. Can you remember that, John?" Father: Ja, du skulle have nyt køkken. "Yes, you were supposed to get a new kitchen".

Mother: Og du skulle installere. "And you were supposed to set it up".

Father: Og der blev installeret. "And it was set up".

Mother (highly pregnant) laughs.

Their daughter Sus: Gider I lige? "Do you mind?” (Jul., afs. 1, 04:33)

The analysis of the data makes it possible to conclude that the verb gide is frequently used in the prohibitive function and not necessarily in combination with the verb lige:

(9) La Cour to Fischer: Gider du holde op med det (rygning) herinde (inde i bilen)? "Would you mind stopping that (smoking) in here (in the car)?” (R., s. 4, afs. 1, 33:15)

(10) Tom's mother to a policeman: Gider du ikke slukke for det horn (politisirene)? "Would you mind turning that honking off?" (police siren) (Jul., afs. 11, 09:59)

(11) Lotte to her friend: Og gider du godt lade vare med at flirte med min nabo, Sigrid! "Can't you stop flirting with my neighbour, Sigrid!” (Mvpc, afs. 3, 20:54)

Contrary to questions with gider, requests with vil/ville can be used in an official setting and in correspondence as the most polite of all conventional questions. They appeal to the willingness of the addressee to perform an action and, sooner than questions with kan/kunne, they are meant at saving a 'negative face' of the interlocutor (the term denoting 
the natural wish of the interlocutor not to be hampered by outsiders). Yet, on the other hand, it is more difficult to answer these questions in the negative since the implicit reason for refusal will be the hearer's lack of willingness and not the external factors [Mosegaard Hansen, 1998, s. 25-26]. In the same way as in questions with gider, vil can be used without modal particles (12), with negative ikke (13), (14), (16), (17) and modal particles lige (14), godt (15), (16), and nok (17).

(12) A reader to the writer signing his books: Vil du skrive her? "Can you sign here, please?" (Fr., afs. 1, 23:07)

(13) Policeman to bank employees: Vil I ikke fortolle om Nicky Rasmussens generelle økonomiske forhold? "Can you just tell us about Nicky Rasmussen's general financial situation?” (B., s. 3, afs. 7, 6:55)

(14) Signe to her little-known stepbrother Frederik in the flower shop where she works and which she is to close at the end of the working-day:

Vil du ikke lige vende dig om så jeg kan gemme dem her (pengene)? Undskyld. Bare så du ikke ser... "Can't you just turn round so that I can hide this (money)? Sorry. Just so that you won't see..." (Arv., s. 1, afs. 4, 23:20)

(15) Gaby to Johnny on the answering machine: Hej, det er mig. Vil du godt ringe med det samme? "Hi, it's me. Can you ring me back at once?" (R., s. 3, afs. 12, 25:24)

(16) Tilde to classmates: Vil I ikke godt skrive under? Kom nu. Please? "Can you just sign this? Come on. Please?" (Kl., s. 1, afs. 3, 3:25)

(17) Woman who has lost her family, in the hospital ward to Unit One’s boss: Vil du ikke nok gå? "Can't you just go?” (R., s. 3, afs. 9, 25:07)

These particles convey the same pragmatic meanings as they do in combination with gider. Contrary to the particle godt, which in indirect requests enhances the positive meaning of the utterance, the particle nok conveys the speaker's doubt in the speaker's possibility or the hearer's willingness to perform an action [Togeby, 1979, p. 20; Krylova, 2004, p. 98], owing to which the question (17) turns into an insistent request.

Vil can also be used with verbs of the final phase in the prohibitive function. 
Mother, irritably, to her younger daughter who is fiddling around with the candles:

(18) Alma, vil du godt lade vare med det der? "Alma, can you just stop that?" (playing with the light) (Theo, afs. 20, 3:40)

(19) Andreas to his girlfriend Signe:

- Hey, hold op! Du kan ikke stå og råde i hendes papirer. "Hey, stop that! You can't just rummage around in her papers".

- Jeg skal have den kontrakt. "I need that contract".

- Vil du ikke godt stoppe? "Can you please just stop?" (Arv., s. 1 , afs. $6,7: 25)$

Questions with kan/kunne appeal to the addressee's possibility of performing an action and are classed among polite requests in the Danish language. Yet, according to Mosegaard Hansen, they are not as polite as those in the French and English languages [Mosegaard Hansen, 1998 , s. 25]. Kan in questions can be used without modal particles (20), with negative ikke (21), (24) and with modal particles lige (22), (23), bare (24), måske (25), as well as be accompanied by extra markers of politeness (22), (23).

(20) Nurse to Theo, whose grandfather is at home in a coma:

Jeg er bare lige ved at vende ham. Kan du rakke mig puden?"I'm just turning him over. Can you give me the pillow?" (Theo, afs. 12, 15:49)

(21) Policeman to a colleague: Kan du ikke få en kendelse? "Can't you get an order?" (B., s. 3, afs. 3, 5:16)

(22) Nicky to his little son: Kan du lige blive og lege, skat? "Can't you just stay and play, kiddo?"' (B., s. 3, afs. 7, 14:38)

(23) Granddad to his grandson: Theo, kan du lige raeke mig den skitse der? Så er $\boldsymbol{d u}$ sød. "Theo, can you just hand me that sketch? Thanks a lot. There's a good lad". (Theo, afs. 1, 12:52)

(24) Theo to his parents: Kan I ikke bare lade mig veere i fred? "Can't you just leave me alone?" (Theo, afs. 14, 17:18)

(25) Faun to a girl: Så kan du måske fortoelle mig, hvad man siger om mig her på Jorden? "Then maybe you can tell me what they're saying about me here on Earth?” (Theo, afs. 20, 6:58)

Combinations with the particle godt are possible, but the assembled data does not feature them. In insistent requests in colloquial speech, 
the borrowed English please sometimes occurs, filling the lexical gap in the Danish language. It usually has a narrower pragmatic function: it is a 'please of begging' pronounced with a lengthened vowel and characterized by a specific intonation [Levisen, Waters 2015, p. 250].

(26) Theo to the fantasy creature: Undskyld, men kan du ikke please hjolpe os op herfra? "Sorry, but couldn't you please help us out of here?" (Theo, afs. 6, 7:15)

Questions with kan can also be subject-oriented and express not only a request for action but also for permission (27) or they may introduce a suggestion (28):

(27) Granddad to the attending doctor:

Kan jeg så ikke tage hjem? Jeg vil faktisk vore hjemme hos mig selv. "Can't I go home then? I'd just like to be at home". (Theo, afs. 2, 3:44)

(28) Alf to his mistress:

Kan vi ikke snakke om noget andet end arbejde? "Can't we talk about something else than work?” (B., s. 3, afs. 7, 35:01)

Questions with kunne, distinguished with a higher degree of doubt, are regarded as more polite.

(29) A policeman trying to ease a conflict between colleagues: Kunne vi lige prøve at tale ordentligt? "Can we just try to speak properly to one another?” (B., s. 3, afs. 2, 40:07)

With a significant gap in the authority between the parties, such utterances can be accompanied by extra markers of politeness.

(30) The teacher to the pupil who does not want to have a classmate in her project:

Sara, kunne du ikke godt voere sød at give Tilde lidt plads. Husk $n u$, at to er bedre end en. "Sara, can't you be nice and give Tilde a bit of space. Remember that two are better than one". (Kl., s. 1, afs. 3, 3:42)

Questions with the verb in the present tense also belong to the most common strategies as they correspond both to the principles of politeness and efficiency [Talbro, 2000, s.15]. Frequently the situation itself presupposes the emergence of such a request since the communicants 
are engaged in a common activity and the result of the proposed action is of mutual interest, and not only in the interest of the speaker. Here, with the request thus worded, especially in combination with lige, it is virtually impossible for the hearer to refuse [Levisen, Waters, 2015, p. 254]. Such questions can be used without modal particles (31), with negative ikke (32), (34) and the modal particle lige (33), (34). Since a request often demands an immediate response without being insistent, combination with godt and nok do not occur.

(31) Wife to her husband, while opening the boot: Tager $d u$ poserne? "Can you take the bags?" (Arv., s. 1, afs. 4, 9:02)

(32) Sus to her friend Bob: Giver du ikke et nummer på din cello? "Don't you want to play something on the cello?" (Jul., afs. 7, 15:29)

(33) The restaurant's proprietor to the cook: Tander du lige ovnen? "Can you just put the oven on?"(Nårst, s. 1, afs. 4, 07:32)

(34) Gro to her father: Thomas, hjoelper du ikke lige? "Thomas, can you give me a hand?” (Laying the table) (Arv., s. 1, afs. 3, 41:04)

Thus constructed, these questions can also be taken as an invitation.

(35) Boss of Unit One to a colleague: Går du ikke med op til et glas vin? "Want to go up and have a glass of wine?" (R., s. 3, afs. 10, 31:54)

The construction er du sød at (lit. 'are you sweet to') has a more polite variant vil du være sød at and a more unceremonious one in the form of imperative vær (lige) sød at. Moreover, as an extra marker of politeness the constructiion så er du sød is used in postposition to the main request, as in (23) or as part of predicative (kunne) være sød, as in (30). The examined data feature largely the forms of the present tense and most examples reveal a significant authority gap between the interlocutors wherein the superiors have to resort to a polite form of request to mitigate their will expression. The particles fitting this construction included ikke, lige and a single bare.

(36) Doctor to a patient's daughter: $\boldsymbol{E} \boldsymbol{r} \boldsymbol{d} \boldsymbol{u}$ sød at vente her? "Would you mind waiting here?" (Arv., s. 1, afs. 1, 36:44)

(37) Teacher to a pupil: $\boldsymbol{E} \boldsymbol{r} \boldsymbol{d} \boldsymbol{u}$ ikke sød at sotte Theo ind $i$ juleopgaven? "Can you just explain the Christmas assignment to Theo?” (Theo, afs. 5, 2:29) 
(38) Boss to a policeman: Alf, er $\boldsymbol{d u}$ sød lige at komme ind på mit kontor? Og sluk lige den cigaret, ikke? "Would you mind coming into my office, Alf? And can you put your cigarette out?" (B., s. 3, afs. 9, 42:56)

(39) Policeman to homeless Ginger: Er $\boldsymbol{d u}$ sød lige at trcede ud en gang? "Can you just step out for a moment?" (Nårst, s. 1, afs. 3, 41:31)

The analysis makes it possible to conclude that conventional requests with gide, vil, kan verbs in the present tense and the construction er $d u$ sød at constitute common strategies in the Danish language. The most polite are questions with vil/ville, er $d u$ sød at, kan/kunne. Questions with gide are used when the social-and-status distance between interlocutors is negligible. The choice between gide and vil can be determined by the age factor, but is has not been confirmed by the results of our study, which may be accounted for by the young age of scriptwriters of the series under study. Combinations of gide and vil with verbs of the final phase allow us to speak about the prohibitive function of such constructions. In the case of questions in the form of the present tense, communicants, as a rule, are engaged in common activity and the result of the proposed action is in common interest and not only in the interest of the speaker. Characteristic of the request speech act is the use of modal particles, first of all, ikke and lige. The particles godt and nok are used in insistent requests, and combinations with bare imply an optimal action to solve the existing problems.

\section{ABBREVIATIONS}

Arv. = Arvingerne, 2014-2017 (The Legacy)

B. = Bedrag, 2019 (Follow the Money)

Jul. = Julestjerner, 2012 (lit. Christmas Stars)

Theo $=$ Theo \& den magiske talisman, 2018 (Theo \& The Magic Talisman)

R. = Rejseholdet, 2000-2004 (Unit One)

Nårst. = Når støvet har lagt sig, 2020 (When the dust settles)

$\mathrm{Mvpc}=$ Mens vi presser citronen, 2015 (lit. While we squeeze a lemon)

Fr. = Fred til lands, 2019 (lit. Peace in this land)

Kl. = Klassen, 2016-2019 (The Class)

s. $\quad=$ sæson (series)

afs. $=$ afsnit (episode) 


\section{REFERENCES}

Andersen B. Høflighed uden grcenser - om du \& De og den måde vi behandler hinanden på. Forlaget LIVA, 2014. 423 s.

AP L. Fucking flink. Hvordan bliver verdens lykkeligste folk også verdens flinkeste? København, 2010. $191 \mathrm{s.}$

Bjerrum M. Om brugen af du i stedet for man. Mål og Moele, 3, november 1995. S. 12-15.

Booth M. The almost nearly perfect people. Moscow: Izdatelstvo "E” Publ., 2017. 512 p. (In Russian)

Brown P., Levinson S. Politeness: Some Universals in Language Usage. Cambridge: Cambridge University Press, 1987. 345 p.

Christensen M. Bloererøvens guide til moderne etiquette. København, 1999. $234 \mathrm{s.}$

Christensen T.K. Tag nu bare økomælken: Om imperative og modalpartikler i dansk. Dramatikken i grammatikken: Festskrift til Lars Heltoft. Roskilde: Roskilde University, 2009. S. 51-67.

Christensen T.K. Tænk bare! Det er ikke så ligetil med den imperativ. Mål og moele, 1, 2008. S. 23-27.

Dansk Sproghistorie, Bind 3, Bøjning og bygning. Det Danske Sprog- og Litteraturselskab, Aarhus Universitetsforlag, 2019. $436 \mathrm{~s}$.

Den Danske Ordbog. Available at: https://ordnet.dk/ddo (accessed: 31.07.2020).

Durst-Andersen P. Bag om sproget. Det kulturmentale univers $i$ sprog og kommunikation. København: Hans Reitzels Forlag, 2011. 200 s.

Durst-Andersen P. Imperative frames and modality, Linguistics and Philosophy 18, Kluwer Academic Publishers, 1995. P. 611-653.

Faerch C., Kasper G. Internal and external modification in interlanguage request realization. Cross-cultural Pragmatics: Requests and Apologies. Norwood, NJ: Ablex Publ., 1989. P. 221-247.

Fredsted E. Politeness in Denmark: Getting to the Point. Politeness in Europe. Nova Scotia; Canada, 2005. P. 159-173.

Grice P. Logic and Conversation. Syntax and Semantics, V.3: Speech Acts. New York: Academic Press, 1975. P. 41-58.

Gurova E. The Thou-You forms of communication in the Danish language. Synchrony; Diachrony; Textology: Collection of academic articles and translations: Commemorating E. M. Chekalina's jubilee. Moscow: MAKS-press Publ., 2016. P. 139-147. (In Russian)

Gurova E. Politeness strategies in Danish directives and requests. Vestnik of Moscow State Linguistic University. Humanities. Issue 834. Moscow: FSBEI HE MSLU, 2020. P.69-84.

Gurova E. Verbal and non-verbal forms of greeting/parting in the contemporary Danish language. Scandinavian Philology, 2017, vol. 15, issue 2. P.204-222. https://doi.org/10.21638/11701/spbu21.2017.204. (In Russian)

Hagemann H. Hej, du dér - Brugen af du og De gennem 30 år i personlig belysning. Sproget her og nu. Dansk Sprognævn, 1988. S. 136-145. 
Hansen E. Imperativ. Mål og moele, 3, 1974. S. 7-13.

Hansen E. Skulle vi ikke vare Des? Mål og Mocle, 1, maj 1998, S. 19-20.

Hansen E. Ta' og hils det hele fra mig - imperativisk ekspansion el. serie-imperativ. Mål og moele, 2, 2002. S. 19-22.

Hansen E., Heltoft L. Grammatik over det Danske Sprog, Bind II. Det Danske Sprog- og Litteraturselskab, 2011. 1167 s.

Heinemann T., Steensig J. Three imperative action formats in Danish talk-in-interaction. Imperative Turns at Talk. Eds M-L. Sorjonen, L. Raevaara, E. CouperKuhlen. John Benjamins Publishing Company, 2017. S. 139-173.

Heinemann, T. 'Will You or Can't You?': Displaying Entitlement in Interrogative Requests. Journal of Pragmatics 38, 2006. P.1081-1104. https://doi. org/10.1016/j.pragma.2005.09.013.

Holberg, O. Opfordringer på dansk, russisk og engelsk i teori og praksis. Ny Forskning i Grammatik, 21, 2014. S. 123-143.

Hørning G. Moderne hilsekultur - et område uden konsensus. Hilseformer og høflighed. Modersmål-Selskabet, 2015. S. 65-82.

Jenkins R. Being Danish: Paradoxes of Identity in Everyday Life. Museum Tusculanum Press, 2011. 355 s.

Jensen E. S. Godt og gerne - modalitet og polaritet. 6. Møde om udformning af Dansk Sprog til minde om Peter Skautrup 1896-1996. Århus, 1997. S. 154-164.

Jespersen O. The Philosophy of Grammar. London: George Allen \& Unwin Ltd., 1924. $360 \mathrm{p}$.

Lakoff R. The logic of politeness, or, minding your p's and q's. Papers from the Ninth Regional Meeting of the Chicago Linguistics Society. Chicago, 1973. P.292-305.

Krylova E. Danish particles as markers of speaker's communicative strategies. Scandinavian Philology. Issue XIII. St. Petersburg: St. Petersburg University Press, 2015. P. 94-103. (In Russian)

Krylova E. Functional semantics of Danish modal particles bare, blot and kun. Scandinavian Philology $=$ Scandinavica. Issue XII. St. Petersburg: St. Petersburg University Press, 2012. P. 75-85. (In Russian)

Krylova E. Modal operators of desirability in the Danish language. Synchrony; Diachrony; Textology: Collection of academic articles and translations: Commemorating E.M.Chekalina's jubilee. Moscow: MAKS-press Publ., 2016. P. 186-194. (In Russian)

Krylova E. Pragmatic semantics and communicative functions of the modals particles nok, vel, vist in the Danish language. PhD thesis. Moscow, 2004. 212 p. (In Russian)

Krylova E. The status of modal particles in Danish and their order in the sentence. Scandinavian Philology = Scandinavica. Issue X. St Petersburg: St. Petersburg University Press, 2009. P. 112-121. (In Russian)

Larina T.V. The category of politeness and the communication style: Juxtaposition of English and Russian linguocultural traditions. Moscow: Manuscripts of Ancient Russia Publ., 2009. 512 p. (In Russian) 
Nikulicheva D. B. The dynamics of the imperative in the contemporary Danish language: strengthening of analytic tendencies. Dynamic processes in Germanic languages. Proceedings of the Fourth linguistic readings in memory of V.N. Yartseva. Moscow-Kaluga: The Eidos Publishing House, 2012. P.6173. (In Russian)

Leech G. N. Principles of pragmatics. London; New York: Longman, 1983. 264 p.

Levisen C., Waters S. Lige, a Danish "magic word" ? An ethnopragmatic analysis.

International Journal of Language and Culture 2:2 (2015). P. 244-268.

Lund J. Adieu. Helt vildt fedt. Gads Forlag, 2008. S.51-53.

Lund J. Hilsener, knus og afklapsninger. Dansk i skred. 52 sproglige opstrammere. Gads Forlag, 2014. S.37-40.

Lund J. Var så dær? Dansk i nullerne. 50 sproglige diagnoser. Gads Forlag, 2011. S. 72-74.

Lund J. Vi snakkes. Hilseformer og høflighed. Modersmål-Selskabet, 2015. S. 13-19.

Mosegaard Hansen M. B. Sproglig høflighed. RIDS, Nr. 143. Romansk Institut, Københavns Universitet, 1998. $31 \mathrm{s.}$

Nikulicheva D. B. Ordre eller opfordring? Direktive sproghandlinger i dansk-russiske filmoversættelser. Globe: A Journal of Language, Culture and Communication. Special issue 1. Aalborg University, 2016. P.96-106.

Ogiermann E. Politeness and in-directness across cultures: A comparison of English, German, Polish and Russian requests. Journal of Politeness Research 5, 2009. P. 189-216. https://doi.org/10.1515/JPLR.2009.011.

Olesen P. Høflighed - hvad blev der af den? København, 2009. $104 \mathrm{~s}$.

Palmgren U.G. Diskret som en dansker. Håndbog i høflighed - kulturelle koder $i$ 11 EU-lande. København, 2008. S.9-12.

Ronnøe L. "Hvor er det dejligt at se dig" - hilsners betydning for arbejdsglæde. Hilseformer og høflighed. Modersmål-Selskabet, 2015. S.21-31.

Rykov Ibsen O. An empirical cross-linguistic study of directives. Doctoral dissertation in Intercultural Business Communication. Copenhagen Business School, 2016. $358 \mathrm{~s}$.

Samtalegrammatik. Available at: https://samtalegrammatik.dk/opslag/artikel/imperativ-lige/ (accessed: 27.07.2020).

Searle J. R. Indirect speech Speech Acts. Syntax and Semantics, 3. New York: Academic Press, 1975. P. 59-82.

Sprogligheder (Gider du med ud?). MålઐMoele, 1, 20. årgang, maj 1997. S. 3-4.

Spørgsmål og svar (Gider ikke (at) være voksen). Nyt fra Sprogncevn, 4, december 2015, S. 14-15.

Steno T. Longsel efter faste former - en temperatur på dansk høflighed og vores omgang med hinanden. København: Multivers, 2011. 109 s.

Talbro B. A. C. Kú du ikke lige? - om at bede om hjælp på en høflig måde. Mål og moele 4, 2000. S. 14-23.

Tal ordentligt. Available at: https://www.callme.dk/om-call-me/tal-ordentligt// (accessed: 20.07.2020). 
Togeby O. Nok. Mål \& Moele 3, 6.årgang, 1979. S. 18-23.

Wierzbicka A. Cross-cultural pragmatics: The semantics of human interaction. Vol. 53. $2^{\text {nd }}$ ed. De Gruyter Mouton, 2003. 540 p.

\section{Елена Гурова}

Санкт-Петербургский государственный университет

\section{ВОПРОСИТЕЛЬНЫЕ ПРЕДЛОЖЕНИЯ КАК СРЕДСТВА ВЫРАЖЕНИЯ ВЕЖЛИВОСТИ В ДАТСКОМ ЯЗЫКЕ}

Для цитирования: Gurova E. Interrogatives as a way to express politeness in the Danish language // Скандинавская филология. 2020. Т. 18. Вып. 2. С. 225-245. https://doi.org/10.21638/11701/spbu21.2020.201

Несмотря на изменение датского стиля коммуникации, связанного с переменами в социально-политической и культурной жизни датчан в конце 1960-х, и выход из активного употребления ряда вежливых оборотов, в датском языке существуют разные способы для выражения вежливых просьб. К одной из самых распространенных стратегий, соответствующих принципу вежливости и эффективности, относится использование конвенциональных вопросительных предложений с глаголами gide, ville, kunne, глаголами в форме настоящего времени и оборотом $e r d u s ø d$ at. Указанные вопросительные предложения рассматриваются в данной статье на материале диалогов из современных датских сериалов. Самыми вежливыми из всех конвенциональных просьб являются вопросы с vil/ville, которые могут употребляться в официальной обстановке и корреспонденции. Они апеллируют к желанию адресата осуществить действие и направлены в большей мере на сохранение негативного лица собеседника, чем вопросы с kan/kunne. Оборот er $d u$ sød at относится к формулам с высокой степенью вежливости и часто предполагает значительную статусную дистанцию между собеседниками. Вопросы с gide используются, когда социальная и статусная дистанции между собеседниками незначительны. Сочетания gide и vil с фазовыми глаголами конца свидетельствуют о наличии у данных конструкций прохибитивной функции. В случае с вопросами в форме настоящего времени коммуниканты, как правило, вовлечены в общую деятельность, при чем результат от предполагаемого действия часто находится в общих интересах. Характерной чертой речевого акта просьбы является использование модальных частиц, прежде всего ikke и lige. Частица lige является особой культурно-специфичной лексемой, которая сигнализирует о незначительности услуги, оказываемой слушающим, однако несмотря на уменьшение угрозы со стороны говорящего, его волеизъявление оказывается навязанным, так как говорящий сам решает за слушающего, насколько незначительна его просьба. Частицы godt и nok используются в настойчивых просьбах, а сочетания с bare подразумевают оптимальное действие для решения имеющейся проблемы.

Ключевые слова: датский язык, вежливость, вопросительные предложения, косвенные просьбы, стиль коммуникации.

* Работа выполнена при поддержке Российского фонда фундаментальных исследований (РФФИ), грант № 19-012-00146. 


\section{Elena Gurova}

PhD in Philology, Associate Professor,

St. Petersburg State University,

7-9, Universitetskaya nab., St. Petersburg, 199034, Russia

E-mail: e.gurova@spbu.ru

\section{Гурова Елена Александровна}

кандидат филологических наук, доцент,

Санкт-Петербургский государственный университет,

Россия, 199034, Санкт-Петербург, Университетская наб., 7-9

E-mail: e.gurova@spbu.ru

Received: August 9, 2020

Accepted: September 11, 2020 